\title{
KASHMIR AND THE NORTHERN AREAS OF PAKISTAN:BOUNDARY-MAKING ALONG CONTESTED FRONTIERS
}

\author{
Hermann KReutZmann \\ With 5 figures, 1 table and 2 photos \\ Received 24 June $2008 \cdot$ Accepted 11 August 2008
}

\begin{abstract}
Summary: Boundaries as known to us and delineated on maps were introduced in the Hindukush-Karakoram-Himalaya ranges in the late $19^{\text {th }}$ century. The results of the "Great Game" have created major sources for conflicts and war. Kashmir, the Siachin Glacier and the Northern Areas of Pakistan are prime examples of virulent disputes which are still hot issues today. This contribution aims to identify the historical background and stage-wise developments which led to the present stalemate. The status of the Northern Areas is a legacy from the British Raj and is rooted in the overall Kashmir conflict arena. The present contest for more autonomy and representation in the federal institutions is linked to the country's uneven participatory approach that is reflected in spatial entities confronted with extra-constitutional status, application of colonial rules, and implementation of indirect rule in tribal areas as well as direct administration of disenfranchised people by the centre of power. The process of slowly adjusting and changing the position of the Northern Areas has created conflicts and confrontation along different lines. Borders are identifiable results of conflict constellations and administrative attempts for their resolution. The region studied represents a case in point for restructuring territories that remain under dispute. Besides international conflicts over space there are internal disputes on different levels of society. Contested administrative setups, demands for equitable quota systems and legitimate representation in public services, regionalism and sectarian clashes form the spectrum of social, spatial and political boundary-making in the Northern Areas. The frontiers are contested grounds and boundary-making is a continuing process. This contribution aims at understanding the actors, driving forces and stakeholders in their respective arenas of contest.
\end{abstract}

Zusammenfassung: Im Hochgebirgsraum von Hindukusch, Karakorum und Himalaya wurden Ende des 19. Jhs. internationale Grenzen demarkiert, die bis heute ihre Gültigkeit behielten. Die Ergebnisse des „Großen Spiels“ um territoriale Dominanz in Hochasien erzeugten ein bis heute konfliktreiches Erbe. Der Kaschmir-Konflikt, der Siachen-Gletscherkrieg und der Territorialdisput um die pakistanischen Nordgebiete sind prominente Beispiele der Gegenwart. Der Beitrag greift die Wirkung historischer Stationen auf und analysiert ihren Beitrag zur heutigen Konfliktkonstellation. Der völkerrechtlich ungeklärte Status der pakistanischen Nordgebiete ist ein Erbe des britischen Kolonialimperiums und ist Teil des ungelösten Kaschmir-Konflikts. Gleichzeitig beinhaltet er innenpolitische Komponenten, die auf die fragile Konstellation der Islamischen Republik Pakistan zurückgehen. Unterschiedliche konstitutionelle Zuordnungen, vorenthaltenes allgemeines Wahlrecht und abweichende Rechtspflege spannen den Konfliktraum auf, der immer wieder zu Anpassungen verwaltungstechnischer und grenzmarkierender Art herausfordert. Die pakistanischen Nordgebiete sind ein Beispiel für Restrukturierungsversuche im Sinne einer Abmilderung konfliktreicher Konstellationen durch Verwaltungsreformen. Dennoch flammen regelmäßig gewaltsame Auseinandersetzungen auf und verschiedene Interessengruppen artikulieren ihre Forderungen nach Autonomie und Teilhabe. Ausgeprägter Regionalismus, Durchsetzung eines Quotensystems bei der Vergabe öffentlicher Ämter und Einforderung eines allgemeinen Wahlrechts sind ebenso Felder des Aufeinanderprallens unterschiedlicher Interessen wie Darstellungen der im Norden Pakistans vorhandenen Glaubensrichtungen in staatlichen Schulbüchern. Grenzziehungen auf unterschiedlichen Ebenen charakterisieren Konfliktkonstellationen und Lösungsversuche gleichermaßen.

Keywords: Pakistan, colonial boundaries, geopolitics, political geography, conflicts, Karakoram, Kashmir 


\section{Introduction}

Boundaries are linked to division and convey the message of separation. Territories of dominance are carved out from other structures, incorporated into empires or states ${ }^{1)}$ and defended against outsiders. Softer terms address them as spheres of influence and control areas. In any respect, past and present borders can be perceived as an expression of attribution, interest and power. South Asia is a perfect laboratory to study border issues and separated entities. The present-day nation states are the result of division. People of the subcontinent have experienced tragedies and traumas linked to boundary-making. ${ }^{2)}$ The legacies are felt in everyday affairs when disputed areas, undefined international boundaries and unsolved territorial claims govern the political agenda between neighbours. But even within nation states the division of provinces and the provision of regional autonomy are practices of boundary-making. In Pakistan frequent suggestions have been made to solve issues of regionalism by dividing the existing spatial entities and by creating new provinces. Several models were discussed ranging from a one-unit solution to an approach comprising 14 provinces (TANVEer KaYANI and KHAN 1998). The vast majority of these proposals do not offer any solution for the Kashmir dispute and/or for the status of the Northern Areas. Most suggestions avoid alluding to the "hot issue" of contested territories. Only one author suggested merging the Northern Areas with the neighbouring region into a province called Hazara (Fig. 1). No serious debates emerged from these proposals to solve the unsolved dispute. As these recent proposals regularly omit historical references, it is suggested to retrieve some aspects of the historical developments which led to boundary-making during the British Empire and to relate these findings to the prevailing crises. The disputed boundaries provide ample space for history and memory, for the construction of territorial entities and their importance, for actors and stake-

1) The term "state" carries a heavy burden and is used here in the meaning of "sovereign bounded communities" (cf. Samaddar 2002, xii). Anthony Giddens $(1985,50)$ emphasized upon the interrelationship between nation states and borders. The latter are the result of the formation of the former and therefore a product of nation-state-building.

2) Numerous publications in academic journals, scientific books and fiction refer to partition. Only recently has a new literature emerged which addresses a future that is "making peace with partition" (KUMAR 2005). holders. In the following, the status of the Northern Areas of Pakistan within the Kashmir conflict arena is explored.

\section{Borders}

Borders are often visible and identifiable divisions between different entities. While over long periods the border lines and the related territories were taken as spatial expressions of power and dominance the discussion has shifted in recent years. Two trends are observed: first, in the age of globalization the context of border debates has been widened from a global perspective. Second, the changing relations between borders and society are contextualised and theorized (Delanty 2006; Kreutzmann 2008; Rumford 2006). Emphasis is put on the relations of people and society with "their" borders. Present-day political and social change is embedded in border practices which have deep historical roots and far-reaching effects on the lives of concerned people and diasporas. Communication, mobility and networks across borders, the flow of goods and ideas are affected by boundary-making. At the same time borders remain spaces of political dispute and territorial division in which different actors fulfil a variety of functions and defend their conflicting interests.

Political boundaries separating nation states are the result of developments and the "making of a frontier" (Durand 1899). The second half of the $19^{\text {th }}$ century until the end of the First World War can be perceived as the climax period of imperial intervention, the division of the world, and concomitant boundarymaking. The contemporary debates of geographers, historians, politicians and diplomats focused on the philosophical interpretation of terms such as border, boundary and frontier. ${ }^{3)}$ The implications for practice were discussed under terms such as "stromstrich" and "thalweg", which helped boundary commissions to negotiate on the ground what their superiors discussed as "natural" and/or "scientific borders" in the "Indian Borderland" (Holdich 1909). The debate ranged around the search for obvious solutions to enable colonial administration to work on the ground. The British explorer NEY Elias was in favour of the "hill frontier" as opposed to rivers separating spheres

3) Cf. Alder 1963; Prescott 1965, 1975, 1987; Prescott et al 1977. Prescott (1965, 9-31) grounded concepts of boundary perception by referring to AnCEL, Holdich, Mackinder and Ratzel. The vivid debate in France, Great Britain and Germany has strongly been influenced by these protagonists. 


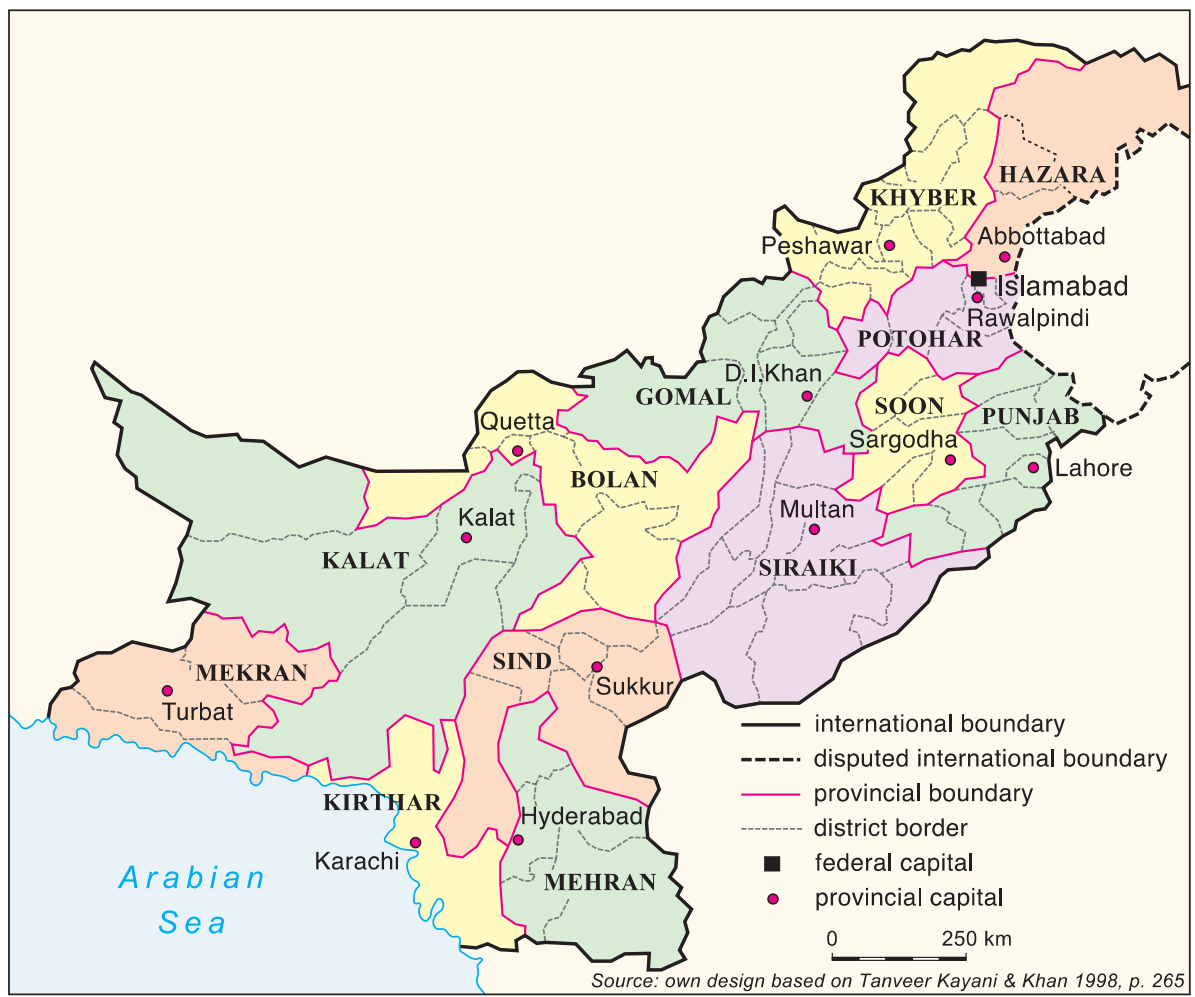

Fig. 1: Suggested provincial division of Pakistan: 14 provinces

of influence. For him, border practice implies fathoming "a possibility of coming to an arrangement with Russia on the subject, under which each party should keep the territory he now possesses. [...] the Afghans should consolidate the territory they now hold in these regions. For this purpose the three chief steps required are (1) to define the boundaries in every direction; (2) either to conciliate or thoroughly overawe the discontented inhabitants; (3) to make no embarrassing claims for more territory, but rather abandon old claims if more desirable boundaries can thereby be secured. They have a large tract of poor mountainous country divided into a number of petty provinces, the borders of which are still open to dispute. These provinces are inhabited by people who have little or nothing in common with the Afghans, and who hate them with the two kinds of which, taken together, make up perhaps the most intense form of enmity. They hate them with race hatred - both Tajik and Turk; and they hate them as conquerors" (ELIAS 1886, 71-72). The statement of NeY Elias shows clearly that the prime interest was to define and separate in order to secure territory. In a second step the affordable cost for the colonial power needs to be assessed, either in establishing indirect rule practices or controlling the people. Both steps are required to find the "desirable boundaries," which he identifies as lying in the high mountain areas.

Information reported by ELIAS in Badakhshan and East Turkestan, the assumption confirmed by the LOCKHART and WOODTHORPE mission (Gilgit, Hunza, Chitral and Wakhan) that the northern mountains were unpassable for a large Russian army, and enquiries by AlgERnon Durand about the weakness of the Kashmiri administration on the Northern Frontier caused Mortimer Durand, the foreign secretary of the British Indian government, to formulate an active British boundary policy for the entire tribal belt between Dera Ghazi Khan in the south and Gilgit in the north (cf. Durand 1888; Elias 1886; LoCKharT and Woodthorpe 1889). Major elements of his plan were diplomatic agreements about the conditions of power at the periphery of the Indian Empire, definition of the boundaries with Afghanistan as a buffer state, and avoidance of direct confrontation between Russia and British India. The cost factor is the guiding principle in finding the appropriate measure in tackling the problems of boundary-making.

The mainstream opinion about dealing with desired territories was contested by some contemporary critics. In numerous articles and commentaries in journals and the London Times Gottlieb 
WiLHELm LeITNER challenged the need for territorial expansion and bringing Britain's borders forward. He influenced the debates and became the advocate of the affected mountain dwellers. Discussions in political and diplomatic circles about the solution of the boundary issue were commented upon in a fierce critique of Britain's colonial policy in the Pamirs and Dardistan. GotTlieb Wilhelm Leitner had the local people in mind and called for the demilitarization and autonomy of the ethnic groups in this region: "The neutralization of the Pamirs is the only solution of a difficulty created by the conjectural treaties of diplomatists and the ambition of military emissaries. Left as a huge happy huntingground for sportsmen, or as pasturage for nomads from whatever quarters, the Pamirs form the most perfect 'neutral zone' conceivable. That the wanderings of these nomads should be accompanied by territorial or political claims, whether by Russia, China, Afghanistan, Kashmir, or ourselves, is the height of absurdity. As for Hunza-Nagyr, the sooner they are left to themselves the better for us, who are not bound to help Kashmir in encroaching on them" (LEITNER 1891, 73).

Nevertheless, LeITNER's adversaries as the advocates of a "forward policy" succeeded in their attempts to secure as much as possible for posterity during the "Great Game". Boundary-making became a major subject in diplomatic training and colonial administration.

\section{Formation and legacies of South Asian boundaries}

South Asia is a prime example and laboratory for experiments and practices in this regard. From the North-West Frontier to the North-East Frontier Agency, the creation of so-called buffer zones including tribal areas, neutralized bulwark states and semi-dependent or fully dependent weak neighbouring countries supported the goal to safeguard the "jewel in the crown", the rich potential of the IndoGangetic Plains. Therefore wealthy princely states such as Kashmir and comparatively poor mountain communities - e.g. Hunza and Nager - became the focus of treaties and agreements, of leaseholds and indirect rule with the aim to lay down boundaries in less-populated and strategically acceptable locations. Boundaries which served the purpose of imperial rule and colonial administration are not necessarily conducive to the aspirations of newly independent states. Especially in cases where partition is a vital element of the independence process and of post-colonial disputes - Bangladesh, India, Pakistan, Burma - these boundaries are of central importance in the arenas of contest. Consequently, boundaries become sources of conflict, interrupt the flow of goods, ideas and people, as well as creating peripheries within nation states. In the case of Kashmir and the Northern Areas there seem to be no mutually accepted maps of border demarcation available. National statistics do not incorporate contested territories and political representation is readily executed from the capital. The centre of power determines the fate in the periphery and reacts sensitively in all cases of internal unrest and border skirmishes.

To perceive the persistence of boundaries and their effects on local populations it seems necessary to elicit the context in which the creation of the Northern Areas of Pakistan is embedded. The debate on the Northern Areas - which formerly seemed to be synonymous with the colonial Gilgit Agency - appears to be a long story, at least much longer than the term has been in use. The Maharaja of Kashmir tried to expand his influence there at the same time when British India and Russia became interested in the Himalaya-Karakoram as well. Consequently, the Northern Areas case is strongly linked to the Kashmir issue. In the Treaty of Amritsar of 1846 the expansionist policies by Maharaja Gulab Singh had been formalized when British India ceded the "hilly or mountainous country with its dependencies situated eastward of the river Indus and westward of the river Ravee"4) to the Dogra rulers. Although the description of the territory is rather vague, it leaves ample scope for contest and expansion. The immediate crisis occurred a century later at the time of partition.

\section{The Kashmir stalemate: roots of a continu- ing dispute}

India, Pakistan and the people of Kashmir disagree about the constitutional and territorial status of the formerly largest princely state of the Indian Empire (Fig. 2). The continuing disputes originate from two perspectives.

First, the implementation of the so-called "twonation theory" has failed in Kashmir. The Maharaja of Kashmir, Hari Singh, who belonged to the Hindu Dogra dynasty, ruled over a population the majority

4) The text of the Treaty of Amritsar is reproduced in Aitchison 1909, XI, 264. 
The Kashmir Stalemate

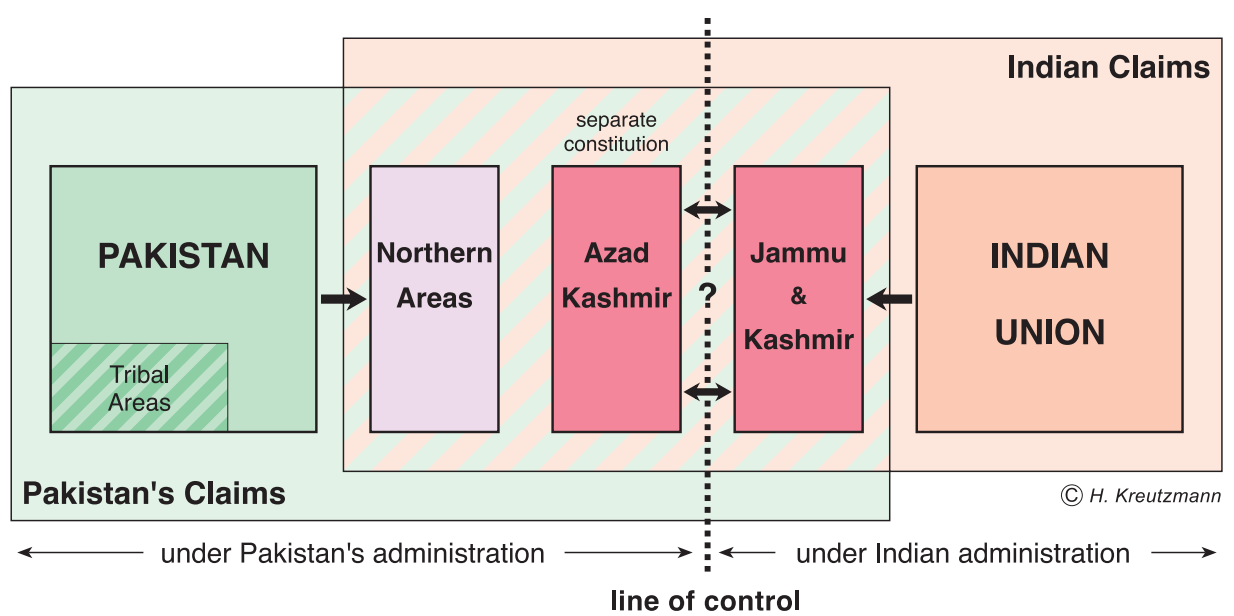

Fig. 2: The Kashmir stalemate

of which followed the Muslim faith. Exceptions to this rule occurred in Buddhist-dominated Ladakh/ Zanskar and Hindu-dominated Jammu. According to the last census before partition (1941), which was taken as the data reference for the "two-nation theory", the population of Jammu and Kashmir was calculated at 4.02 million inhabitants. The religious composition was given as $77.1 \%$ Muslim, 20.1\% Hindu, 1.7\% Sikh, 1.0\% Buddhist, and 0.1\% Christian. Language-wise, the regional differentiation (Fig. 3a) showed a similar patchy and inconsistent picture. Both parameters hint at a difficult decision-making process in Dogra-ruled princely state to perform the transition from British India to either of the newly created independent nation states.

Playing for independence from India and Pakistan, Maharaja Hari Singh deliberately postponed any decision about accession to either side. The story of the 1947-1948 Kashmir war, interference of troops from Pakistan and India, and a UN-negotiated peace treaty has repeatedly been told (cf. KreutzmanN 1995a, 2002; Lamb 1991 for further references). The first Kashmir war broke out shortly after independence in 1947, and the Indian army as well as the Pakistan army were commanded by British highranking officers. The confrontation created a paradoxical situation: in October 1947 Field Marshal Sir Claude Auchinleck was the Commander-in-Chief of both the Indian and Pakistan Armies. Some authors suggest that this fact led to the early involvement of the United Nations in peace negotiations (TARIQ AlI 1983, 65; Lamb 1994, 69). According to Lamb (1994, 71-72) "the opinion of most [contemporary] British observers [...] was that the best solution lay in a parti- tion of the old state of Jammu \& Kashmir, essentially with Ladakh and much of Jammu going to India and the rest to Pakistan." The concept of partition was reiterated by the British UN representative in 1950 but rejected by India and Pakistan in favour of a unitary plebiscite in all of Kashmir.

This confrontation resulted in a cease-fire line separating Indian and Pakistani spheres of influence. With minor deviations it survived the 1965 war, which saw Kashmir as the major military theatre. The Tashkent agreement of January 1966, negotiated between Prime Minister Lal Bahadur Shastri and President Ayub Khan under mediation by the Soviet Prime Minister Aleksei Kosygin, confirmed the status quo and the retreat of troops behind the actual line of control. During the third IndoPakistan war of 1971, Kashmir played a secondary role, and the 1972 Simla Conference extended the status quo again. Since then all demands for an impartial and internationally supervised referendum/ plebiscite on the future status of Kashmir have been postponed. The population distribution pattern in the disputed region has significantly changed (Fig. $3 \mathrm{~b}$ ), which is not only a result of population growth and administrative setups but also reflects the impact of migration and mobility.

Since the mid-1980s, fighting for the control of the Siachin glacier region between specially trained army units has taken place every summer (Fig. 4). The barren tracks of the uninhabited Siachin region form a challenging and remote battleground where both sides are fighting because of the shortcomings of land surveyors' and diplomats' ambiguity in a commercially unproductive territory. 


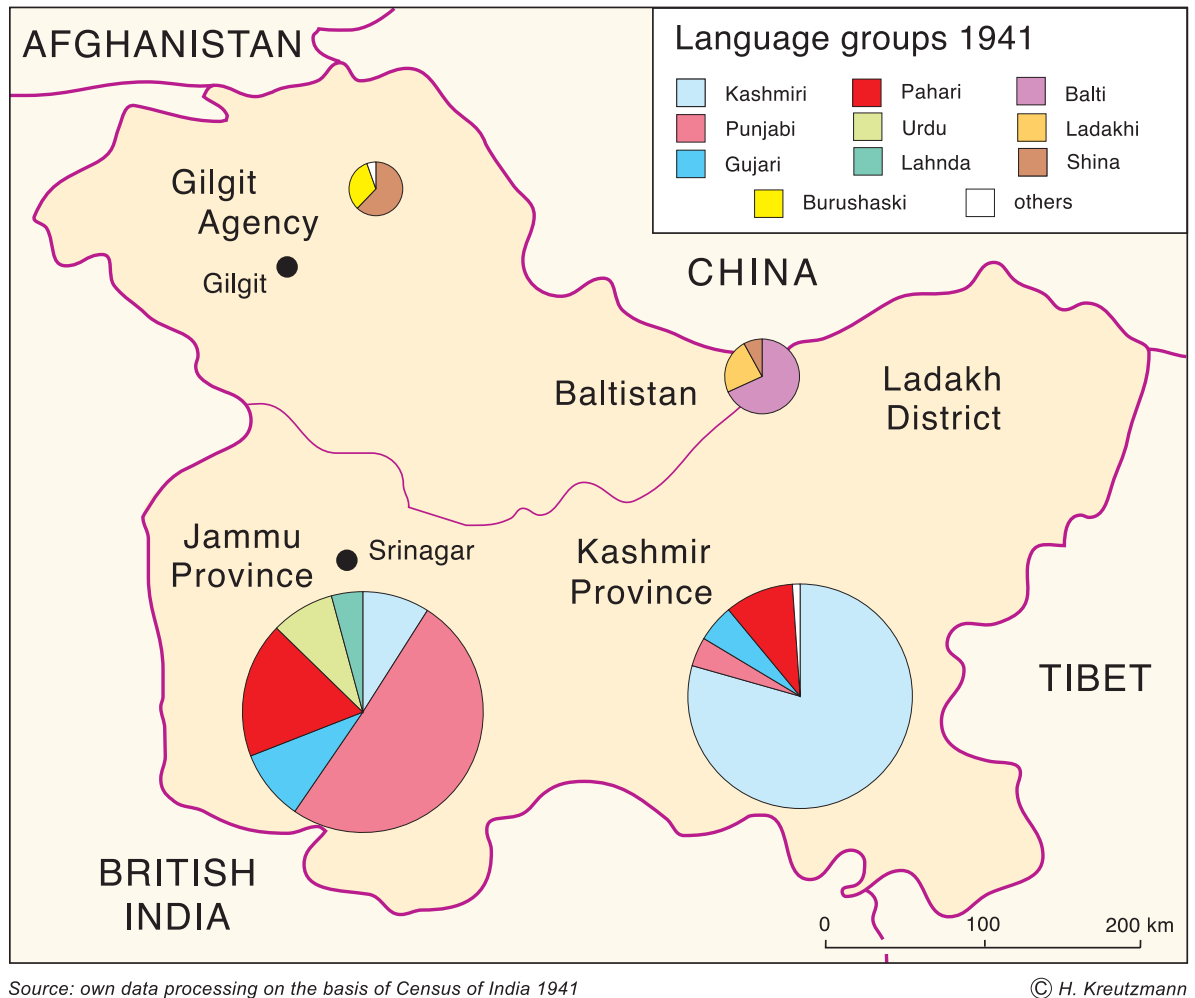

Fig. 3a: Language groups 1941

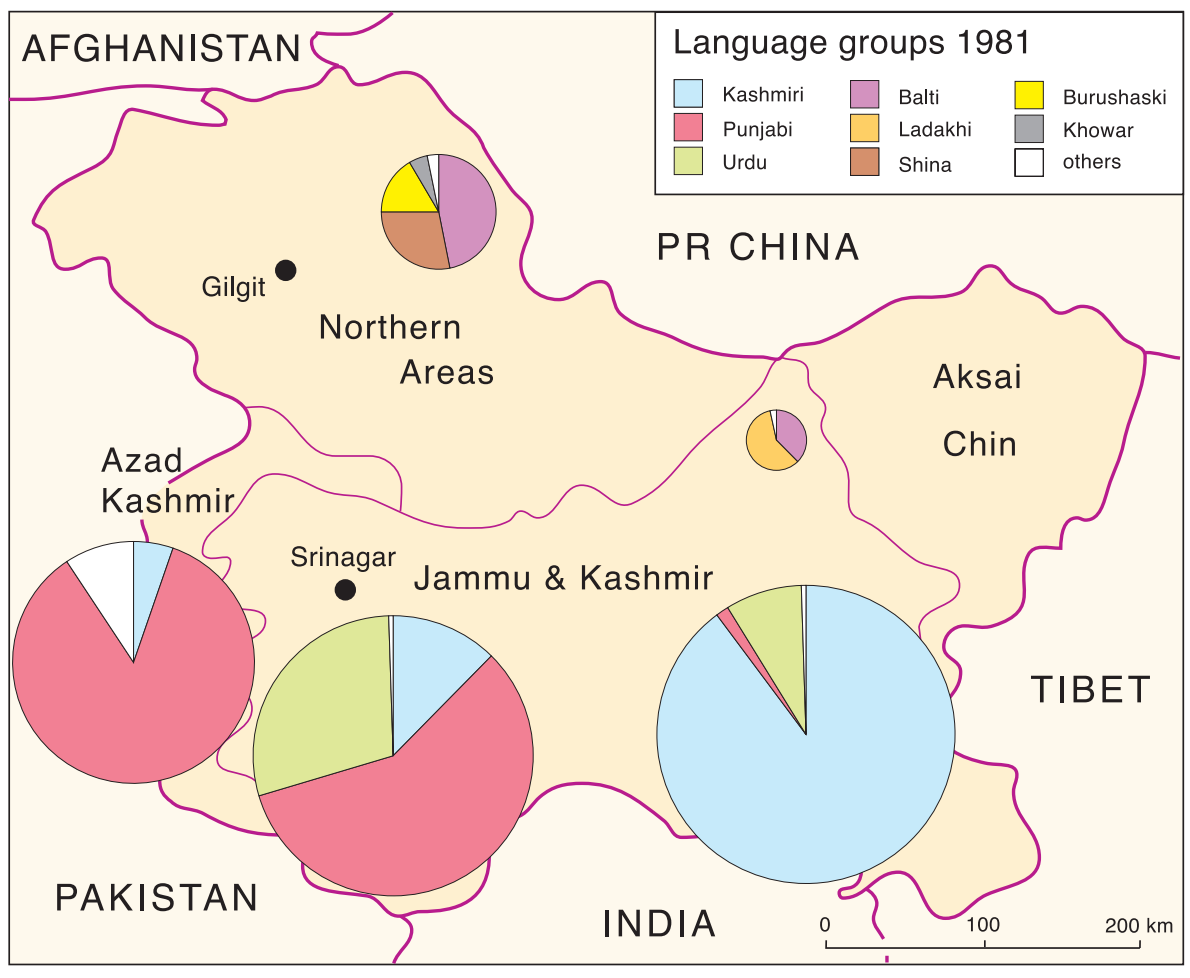

Source: own data processing on the basis of Government of Pakistan 1984, Warikoo 2007

(C) H. Kreutzmann

Fig. 3b: Language groups 1981 


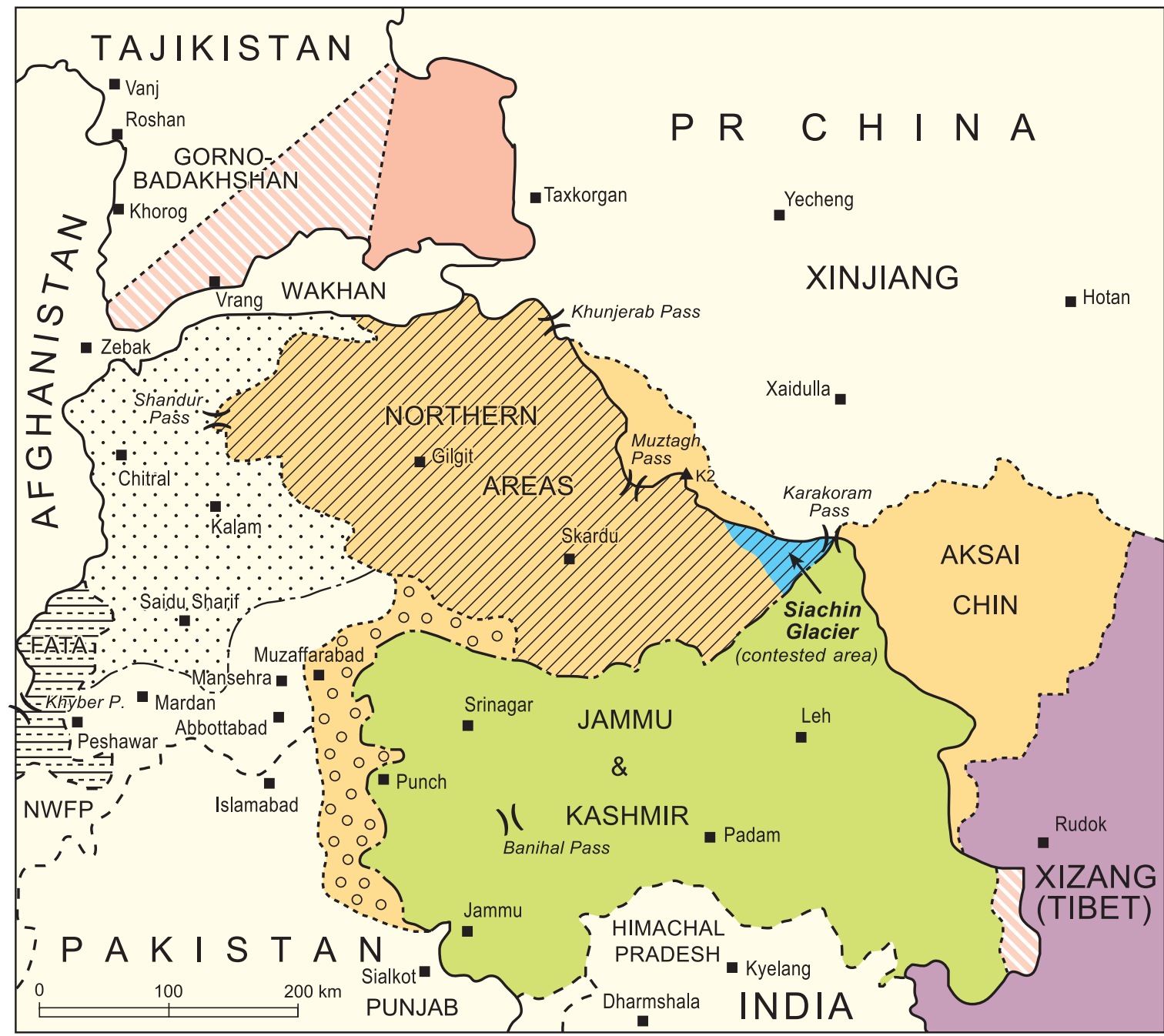

disputed regions

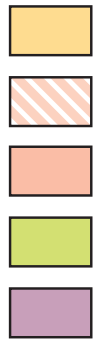

territory claimed by India

territory claimed by PR China

Chinese territory according to Atlas of Xinjiang 1966

territory claimed by Pakistan

territory claimed by Tibetan government in exile administrative regions with special constitutional status in Pakistan

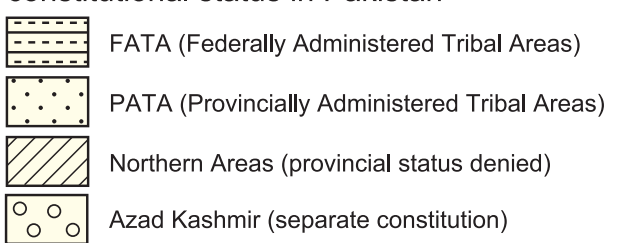

Source: own design according to fieldwork 2001, Kreutzmann 1995, Tajikistan's topography based on Narzikulov \& Stanjukovic 1968, border claims according to Atlas of Xinjiang 1966, p. 149-150

Fig. 4: Disputed territories and constitutional peculiarities in Western High Asia

Unfortunately servicemen from the mountain regions who are adapted to, and who are able to survive in altitudes above $5,000 \mathrm{~m}$ have become the victims of this senseless fight year after year. The Kashmir wars have bound huge amounts of armoury in the Northern regions for a battle between two independent states where local residents are pawns in a competition neither side might ever totally win. In 1999 another war between the two contestants was barely averted when the "Kargil Crisis" led to military encounters, territorial gains and losses, and to numerous victims among the soldiers who mainly originated from the mountain regions. 
A second point should be emphasized because of its importance in related disputes: the extent of the state ruled by the former Maharaja of Kashmir and its status under international law are inconsistent in the demands of all concerned parties. On Indian maps up to the present day, the whole of the Northern Areas - the former Gilgit Agency including the then principalities of Hunza, Nager, and the governorships of Punial, Yasin, Kuh, Ghizer and Ishkoman, the Chilas and Baltistan Districts - are marked as part of Indian Kashmir. According to that opinion, Kashmir borders in the west with Chitral (North-West-Frontier Province) and in the north with PR of China (cf. Fig. 4). But India repudiates the present frontier line with China as well. This delineation originates from the 1963 Pak-Chinese Treaty, which involved a settlement about $8,800 \mathrm{~km}^{2}$ of disputed territory of which Pakistan has since controlled forty percent. In addition, the Chinese claims for Aksai Chin, which followed the construction of the Xinjiang-Tibet road through this uninhabited territory in 1956, are unacceptable for India. Consequently, Indian maps indicate that Aksai Chin is within its national boundaries.

Pakistan's views have changed over time. In the aftermath of the local uprising causing the abolition of Dogra rule in Gilgit and Baltistan, a shortlived "Independent Republic of Gilgit" was established on November 1, 1947, preparing the way for the unanimously accepted accession to Pakistan (cf. Kreutzmann 1989; SöKefeld 1997). Consequently, the official version of the Pakistan Government distinguishes between Kashmir on the one hand and the Gilgit Agency (Northern Areas) on the other. This viewpoint is supported by a lengthy historical investigation and legal interpretation within colonial files regarding the status of certain territories in the Gilgit Agency. In 1941 an internal decision binding for administrative purposes summarized the results of a previous discussion for the two principalities in question: "Hunza and Nagir: - Though these are under the suzerainty of the Kashmir State, they are not part of Kashmir but separate states". ${ }^{5}$ )

This deliberate uncertainty in the formulation of the legal status is one of the obstacles for a negotiated solution. The Government of Pakistan has treated the Northern Areas and Kashmir as separate entities, which is reflected in different constitutional configurations. Azad Kashmir (AK) is governed by

5) India Office Library and Records: Crown Representative's Records - Indian States Residencies - Gilgit, Chilas, Hunza and Nagir Files (Confidential): IOR/2/1086/303. its own President elected from an assembly composed of the AK Parliament and the AK Council. In contrast, the Northern Areas are granted neither provincial status within Pakistan nor a similar semiautonomous parliamentary setup like that of Azad Kashmir (cf. Fig. 2, 3b). In recent years there have been attempts by Azad Kashmir politicians to link the Northern Areas to their issue of pressing for a plebiscite to be held in all of Kashmir. Although this move seems to enhance their chances for a vote in favour of Pakistan - in case a referendum about the aspired affiliation to either side is ever held - outspoken representatives of the Northern Areas refuse to cooperate. In their opinion the struggle for independence succeeded in casting off any relation to Kashmir. In recent times the federal government has moved to combine both regions. These plans have been rejected with the reasoning that there are no ethnic and regional similarities, no traffic links, and no economic exchanges. The inhabitants of the Northern Areas (app. 0.87 million according to the latest population census of 1998) fear domination again by Kashmiri bureaucrats as the population of Azad Kashmir ranges around three million persons. Therefore they advocate an independent province with similar civil rights and representation to those in the other provinces and not a separate constitution like in Azad Kashmir.

Both India and Pakistan claim to be the rightful representatives of the people of Kashmir but in recent years Kashmiri nationalists have promoted the creation of an independent Kashmir composed of Pakistan-controlled Azad Kashmir and Indianheld Jammu and Kashmir Province. This proposal is strongly rejected by both India and Pakistan who have strategic interests in the region and demand their share in the economic wealth of Kashmir. The third option might be the driving force for peace talks and the reconciliation process, which was initiated by Pakistan's President Pervez Musharraf and India's Prime Minister Atal Bihari Vajpayee. In contrast to earlier attempts, it seems that present negotiations might lead to an agreement in the near future. Both countries are now in a position that they cannot afford a continuing interruption of economic exchange and communication. The line of control between India and Pakistan still remains one of the international boundaries with least economic permeability.

The legal framework in the case of Azad Kashmir applies to other high mountain regions of Pakistan as well. The Northern Areas are governed directly from Islamabad under the auspices of the Federal 
Minister for Kashmir Affairs, Northern Areas and Frontier Regions. At the same time the Minister is the Chief Executive, the highest representative of the Northern Areas and an un-elected member of the Northern Areas Council. The inhabitants are still disenfranchised and have no representation in the National Assembly symbolizing continuing regional disparities in the legal status of peripheral regions.

The so-called Tribal Areas are divideded into federally (FATA) and provincially (PATA) administered entities in which no federal or provincial legislation is enacted unless it has been authorized by the President of Pakistan or under him the Provincial Governor through the appointed Political Agent. In recent months the special status of the tribal areas was highlighted when President Pervez Musharraf started military operations in Waziristan and other tribal areas in search of Osama bin Laden, Mullah Omar and their supporters. In Pakistan's domestic policies the special status of the tribal areas was continued over long periods as the so-called "Frontier Crimes Regulations" originating from 1872 were applied until recent times and the Government left internal affairs to the tribal leaders (malik, sardar).

Summing up, the mountain regions of Pakistan in the Hindukush, Karakoram and Himalaya are characterized by a state of uncertainty comprising a special legal status, direct and indirect rule, and a limited validity of certain civil rights. All these peculiarities are linked to colonial and geopolitical legacies. On the other hand, huge subsidies have been allocated to these regions, which fare much worse than the rest of the country when average provincial incomes are compared. Azad Kashmir and Northern Areas have been allocated substantial funds for regional development. These aspects need to be highlighted when it comes to a discussion of participation, governance and civil society.

\section{Central administration and regional con- flicts in Northern Pakistan}

The Northern Areas are neither represented in Pakistan's National Assembly nor in its Senate. The territories strongly claimed by all governments are administered directly from Islamabad via the Ministry of Northern Areas and Kashmir Affairs. Up to now, no minister from the Northern Areas has been appointed. Hence, the constitutional situation in the Northern Areas is clearly different from that in the centrally governed Tribal Areas (FATA) and in Azad Kashmir (AK). The Tribal Areas send rep- resentatives to both houses of parliament and have assumed a major role in forming the government. ${ }^{6}$ The Pakistan-administered parts of Kashmir have been granted their own constitution and autonomous government. Nominally, an independent president represents Azad Kashmir vis-à-vis other countries.

For years the political representatives of the Northern Areas have attempted to end discrimination against them and to obtain the same civil rights on the basis of Pakistan's constitution. The administrative reforms that were heralded on the occasion of President Zulfigar Ali Bhutto's visit in 1972 and subsequently implemented abolished the authority of the traditional élites in Northern Pakistan, leaving a power vacuum. From the start the representatives of the national government in Islamabad were confronted with the local population's demand to be granted the status of a province (Внитто 1972, 173). As an interim solution, a Resident and Commissioner took charge of the newly created districts of Gilgit, Baltistan and Diamir. In 1974 Hunza was the last princely state to be incorporated into the Northern Areas; at the same time two new districts - Ghizer and Ghanche - were created by subdividing Gilgit and Baltistan. An assembly of representatives - the Northern Areas Advisory Council - with 16 elected members became the top regional body, a function it kept until 1999, when it was renamed Northern Areas Legislative Council and its membership and portfolio were expanded (Government of Pakistan (n.d, probably 2004) 6; Sherullah Beg 1976).

During the military dictatorship of Zia-ul-Haq (1977-1988) this administrative structure was modified, and the Northern Areas were reorganized into three districts. ${ }^{7)}$ The administrative centralism practised in the Northern Areas was further strengthened under martial law. In response and parallel to the democracy movement at the national level, a Movement for the Determination of the Constitutional Position of Northern Areas was formed, calling for the

6) Similarities between the Tribal Areas and the region which became known as Northern Areas in the 1970s only occurred in the field of political participation. The "Frontier Crimes Regulations" prohibited activities of political parties in Gilgit and Baltistan until 1972, cf. RIECK 1995, 439.

7) During the period of martial law (1977-1985), the Northern Areas were governed as a separate Martial Law Zone (DANi 1989, 422). Representatives of the Northern Areas merely had observer status even in the Majlis-i-Shora created by Zia-ul-Haq as the predecessor of the present National Assembly. 
constitutional integration of the Northern Areas into Pakistan and electoral rights for the population. Among the committee's demands was the release of imprisoned demonstrators and of judges and public officials who had gone on strike, equal pay for civil servants, and equal grants for students from the region. ${ }^{8)}$ The Kashmiri citizens preferred - and still prefer - union with Azad Kashmir, because the Northern Areas are expected to vote for Kashmir to join Pakistan in a future referendum in accordance with the UN resolution..$^{9)}$ In addition, a Kashmiri ${ }^{10)}$ majority population anticipates economic advantages and administrative jobs in an amalgamated and upvalued province. A resolution presented to President Zia-ul-Haq in 1987 by a prominent representative of the Northern Areas demanded independence and equal opportunities, as well as general infrastructural and economic improvements:

- "The determination of political status.

- Appointment of a local advisor for Northern Areas.

- Reservation of all Northern Areas posts for the people of Northern Areas.

- Participation at local, national and international level.

- Special provision for the participation of people of Northern Areas in all services.

- Establishment of Secretariat like Azad Kashmir in Northern Areas.

- Right to appeal in High Court and Supreme Court.

- Increase in the allocation of seats in professional colleges.

- Reservation of seats in public and other educational institutions for the students of Northern Areas.

- All the services of Northern Areas should be brought at par with Federal Services [...]

8) Salaries of non-local "conscripted" employees were $25 \%$ higher than those of local clerks, and study grants for Northern Areas students were less than half the amounts received by students from the FATA; cf. The Muslim 31.5. and 20.6.1985.

9) The third option under discussion was to make the Northern Areas constitutionally equal to Kashmir, i.e. to allow their own constitution, a parliament, and representation by a President of the Northern Areas. However, this option was soon rejected; cf. LAMB 1991, 158-181 (on the role of the UN); SAlaria 1989.

10) The term Kashmiri is used here to identify citizens of Kashmir and not speakers of the Kashmiri language who are a minority in Azad Kashmir.
- Discouragement of the people responsible for creating religious tension ..."”11)

Yet these demands have been only partially met up to now. During Benazir Bhutto's first term of office (1988-1990), plans to grant provincial status to the Northern Areas became more concrete. After the internal regional subdivision had been increased again to five districts in November 1989, it was planned to introduce a similar model for the Northern Areas to that in the Federally Administered Tribal Areas (FATA). ${ }^{12)}$ The presidentially decreed change in government in Islamabad in August 1990 did not bring any progress. The plan was put on hold. The call for constitutional recognition of the Northern Areas continues, backed up by protest demonstrations and strikes that give momentum to the formation of a regionalist movement. ${ }^{13)}$ Progress was only made after the creation of a three-month interim government tolerated by the army and led by Prime Minister Moeen Qureshi following the riots of summer 1993. The official agreement was:

"The federal government has upgraded the administrative and judicial set up in the Northern Areas without changing the constitutional status of the area.

The Northern Areas will have the chief executive with a status of federal minister. The Judicial Commissioner will be appointed for the area, who will be a serving or a retired judge of the high court. The Northern Area's administration will also have the executive authority like aprovince.

... a greater degree of administrative and judicial autonomy to the Northern Areas administration had been given in order to ensure full participation of the people in the affairs of the country and the area.

The Northern Area's council has been expanded from its present 21 members to 26 members. The Chief Executive of the area would be the chairman of the council, who would appoint three members of

11) The resolution was presented by Dr Sher Zaman in December 1987; quoted after DANI (1989, 426-427). It is characteristic for the dictatorship period that the call to give Northern Areas the right to vote was not included in the list. Nevertheless, innumerable graffiti were written on the walls of public buildings, especially during this period (Photo 1).

12) Cf. The Frontier Post 5.11., 3. and 5.12.1989. The Muslim 27.11.1989. Besides, Benazir Bhutto had appointed advisors from the districts of Northern Areas, hence fulfilling one of the above-listed demands.

13) In 1985 already, many people had been arrested and imprisoned during a general strike in Gilgit. Subsequently, this means of protest was practised frequently, with similar consequences. The movement was advocated mainly by judges and lawyers. Cf. The Muslim 27.8.1991. 
the council as his advisers. The administration of the area would be delegated the powers of the provincial government. [...]

... the law enforcing agencies in the area would also be reorganised and the Chief Commissioner office would also be restructured.

... the Northern Areas administration would be attached with the federal government and it would be answerable to the Federal Government." (The Muslim 5.10.1993, italics by HK)

Demands from earlier petitions were at least partially satisfied. On the one hand, this restructuring gives Northern Areas similar rights to those of a province; on the other, the constitutional status quo is maintained with respect to electoral rights and central administration. ${ }^{14)}$ All amendments were laid down in the Northern Areas Legal Framework Order of 1994, which stated that the Chief Executive would be the Federal Minister for Kashmir and Northern Areas affairs in personal union. Further modifications were applied in 1999 when the Supreme Court urged a solution for the unconstitutional status of the Northern Areas (Dawn 9.7.2003; KHAn 2005). Consequently, the NALC discussed an "Interim Constitution Act" which would enable the Government to assign the Northern Areas the status of a province including all connected institutions. Modelled after the Azad Jammu and Kashmir constitution, an elected president would represent a government consisting of prime minister, minister and legislative assembly. ${ }^{15)}$ Even when in Pakistan an administrative reform was executed to install the "nazim" system the Northern Areas were spared. In 2004, the army still justified the presence of "Army Monitoring Teams" in the Northern Areas although they had been abolished in the rest of Pakistan two years earlier. The Northern Areas Deputy Chief Executive Fida M. Nashad legitimated their existence because "[...] the Northern Areas were not a constitutional part of Pakistan" (Dawn 4.7.2004). Nevertheless, a provincial status has not been

14) Further concessions - including the transfer of budgetary and administrative powers to the Northern Areas Council and lower-level executive organs, as well as the creation of a Chief Court in Gilgit - were announced in April 1994 (AzIZ SIDDIQUi 1994).

15) In addition a full-flung judicial setup including supreme court and high court as well as public service and election commissions were included. "The proposed Interim Constitution Act, 2003, for Northern Areas, comprises 85 articles and 5 schedules" (Dawn 9.7.2003). awarded to the Northern Areas yet. As somewhat of a surprise came the announcement of a "constitutional package" for Northern Areas on October 23, 2007 during the visit of Pervez Musharraf to Gilgit. The NALC has been given the status of a "legislative assembly with powers to debate and pass its budget. The existing council has 36 seats, 24 elected and 12 reserved (six for women and six for technocrats)" (Dawn 24.10.2007). The post of deputy chief executive was renamed and will in future be called "chief executive with full administrative and financial authority and the existing chief executive (a federal minister) would be the chairman of the Northern Areas government ". ${ }^{16)}$ The amendment of the Legal Framework Order (LFO) for Northern Areas includes the transfer of administrative and financial power from the Ministry of Kashmir and Northern Areas (KANA) to the newly named Northern Areas Legislative Assembly (NALA). Although the budget of 7.5 billion PRs is now transferred from the federal government to the Northern Areas for further allocation, the main question of constitutional status remains unresolved. The prescribed terminology within the Government of Pakistan was recently given as: "The areas constitute an integral part of Pakistan, but is not a federating unit". ${ }^{17}$

Consequently, despite cosmetic reforms and amendments of the LFO the verdict of the Supreme Court of 1999 has not been fulfilled up to now. The constitutional limbo is carried forward, the issue of Northern Areas allegiance is intrinsically tied to a solution of the Kashmir dispute and the right of vote in general elections has been repeatedly denied to the inhabitants of the Northern Areas (Photo 1). The implementation of

16) Dawn 24.10.2007, 25.10.2007. In addition the creation of a new district consisting of Hunza and Nager was decreed at the same occasion. In 2004 the new district of Astor was constituted (Dawn 1.8.2005). Until today the dispute about the location of the district headquarter - either in Eidgah or Gurikot - is not solved and was presented in court (Dawn 20.9.2006; 24.1.2007). Immediately the constitutional practice was challenged whether Northern Areas are a part of Pakistan and whether the Supreme Court is cognisant.

17) Government of Pakistan (n.d., probably 2004), 1. This point of view is reflected in the establishment of BashaDiamir dam on the river Indus. The dam construction site was identified at Basha which is located just a few kilometres south of the Northern Areas territory whereas the major volume of the water will be stored in Diamir district of Northern Areas. It seems that the Government of Pakistan wanted to play safe and selected a dam site within the area covered by its constitution and accepted by international law. 
announced reform packages needs to be awaited, probably an attempt by the next caretaker government might resolve some more open issues. ${ }^{18)}$

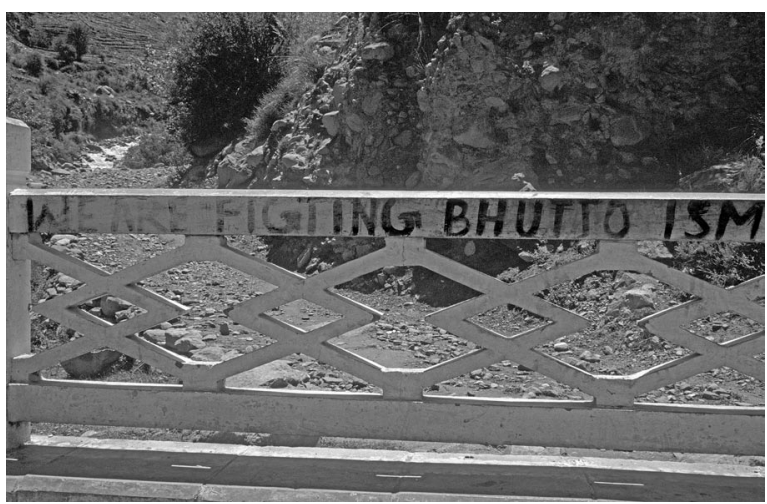

Photo 1: Popular demands for the "right of vote" by student activists in the Northern Areas

\section{Borders on the move, changing regionaliza- tion and stakeholders' impact}

In the former princely state of Chitral, which had been separated from Gilgit in 1896 and incorporated into the newly created North-West Frontier Province in 1901, the Pakistani administration gradually restricted the mebtar's authority from 1953 onwards by appointing a Political Agent. Up to 1969, Chitral, Swat and Dir were under direct control as the Federally Administered Tribal Area, before the traditional rulers lost their last privileges in the course of reforms of social structures. Later, these areas were given their own districts within Malakand Division. In the 1973 constitution, whose basic elements are still valid today, Chitral is a Provincially Administered Tribal Area (PATA) within the NWFP. ${ }^{19)}$ Both administrative areas have a special status in the constitutional reality of Pakistan. These phenomena are primarily due to the persistence of colonial administration principles in border areas rather than to a determined Pakistani nationalities or minorities policy. The territorial borders of administrative units primarily followed pre-colonial and colonial patterns of regional power.

18) Similar announcements of changes in the administrative and budgetary powers of the NALC and its executives had been made earlier on; cf. Dawn 3.11.1999, 30.11.1999, 24.10.2002; MeHmoOd Khan 1996.

19) Cf. Dichter 1967, Fig. 1; Government of Pakistan 1990, 176; Masoodul Mulk 1991, 17.
The administrative setup remains quite clear. The Hindukush regions of Chitral are an integral part of Pakistan as they are incorporated within the NorthWest Frontier Province. The Northern Areas remain in limbo as the provincial status has not yet been awarded. For bureaucrats and administrators this is a straightforward concept. Nevertheless, in recent years international and national donor agencies treat the mountain areas of Pakistan in a different way. They regard the northern mountain fringe ranging from Chitral to Ghanche as an entity which they identify as Northern Areas and Chitral (NAC, Fig. 5). ${ }^{20)}$ Under pragmatic considerations they re-awake a discussion that goes back to colonial times.

Development practice creates new perceptions and handling of space for the purpose of defining project areas and arenas for the implementation of development packages. Development institutions group areas together on the basis of development indicators. Although administrative authorities deny a process of homogenization is at work. In terms of living conditions and participation in economic affairs NAC can be regarded as an entity. The contiguous region of Chitral and Northern Areas remains separated under constitutional rules. Different perspectives and contrasting intentions express a variety of groupings that serve specific purposes. We have discussed the interests of administrations and governments which negotiate a difficult diplomatic and geopolitical terrain. Development institutions create their own entities for the formation of working units. Some observers identify parallel structures by doubling administration and institutions. The concept of project areas and village organizations refers to somehow congruent units of districts, subdivisions and union councils. Both setups represent different world views and are the result of decades of restructuring. Beginning community development based on a Village AID Programme in 1953 was followed by Ayub Khan's "basic democracies" which created the still-valid structure of the Union Council system. Zulfigar Ali Bhutto transformed the "basic democracies" into a "people's work programme" and subsequently introduced an "integrated rural development programme". In the process he abolished "princely rule" and incorporated former independent principalities into the new structure of Northern Areas. Zia ul-Haq experimented with "community basic services" and implemented "local bodies

20) See the evaluation reports by the World Bank and regular reporting from development agencies such as the AKDN (cf. Abdul Malik 2005, 114; Abdul Malik and Izhar Ali Hunzai 2005; World Bank 2002). 


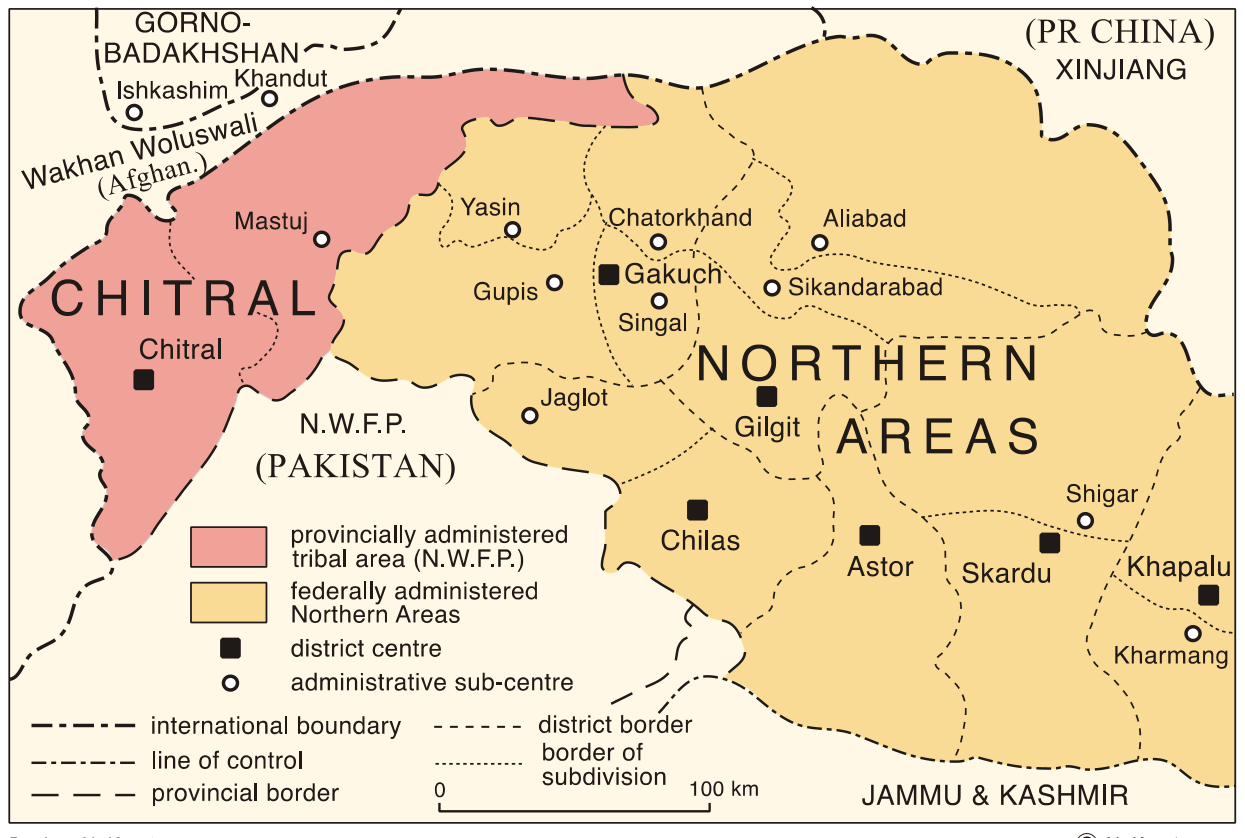

Design: H. Kreutzmann

(C) H. Kreutzmann

Fig. 5: NAC - Northern Areas and Chitral

\& rural development" which amalgamated the concepts of his predecessors. At the same time the effect of the Karakoram Highway was felt and international NGOs started their activities in the field of rural development. Benazir Bhutto addressed the development deficits in the Northern Areas through a "social action programme" which left its mark by providing schools to remote settlements. Pervez Musharraf provided a "poverty alleviation fund" for decentralized development. The administrative reform that reached the provinces and districts of Pakistan has not yet left its mark on the Northern Areas.

\section{Naming games in the mountain belt}

From a rather different perspective "mountain nationalists", striving under the banner of an entity called "Balawaristan" (Photo 2), combine Chitral and Northern Areas and extend their claim eastwards towards Ladakh. Here we encounter an endeavour to establish historical roots for a common cause projected to the mountainous regions. The protagonists of the "Balawaristan National Front" treat Northern Pakistan as a "Pakistanoccupied" territory and interpret the undecided constitutional status in a reverse manner. If Northern Areas are not covered by the Pakistan Constitution, then they should be permitted to create the independent state of "Balawaristan". Somehow the followership of this Gilgit-based movement is rather limited in contrast to the claims they promote via Internet. ${ }^{21)}$ Support for the Balawaristan case is given from Indian activists and diplomats who interpret the term indiscriminately as an historical spatial entity (Raman 2005). Therefore, by constant repetition Balawaristan has been familiarized and entered public discourses.

Historical roots are made responsible for a number of names which have been suggested for the Northern Areas. Bolor is often put forward as a possible term for finding a consensus. Bolor has the advantage that its regional definition is rather ambiguous and vague. ${ }^{22)}$ A variety of authors locate it in a wide-ranging area from the Pamirs and the Karakoram to Kashmir and Ladakh. Somehow they neglect the synonymous use of Bolor for Kafiristan (land of the infidels) in early

21) Reference is given to http://www.balawaristan.net where the aims and objectives of the movement are given; cf. SÖKEFELD 1999, 2005 for an interpretation of aspirations, motives and strategies.

22) One cartographic example for identifying Bolor with the "Massif des Ts'oung-ling (Bolor)" (Onion Mountains) is the map titled "Carte chinoise du Si-Yu ou Asie Centrale pour accompagner le mémoire initulé récit officiel de la conquète du Turkestan par les chinois (1758-1760)" where the "Massif des Ts'oung-ling (Bolor) is located in an area south of Kashgar and east of Wakhan. HolzWARTH (1998) has discussed and interpreted local and regional sources of information. Referring to his in-depth study Bolor and Boloristan comprise an area which some authors project on to nowadays Chitral, Gilgit and Baltistan, others locate a much narrower space. 


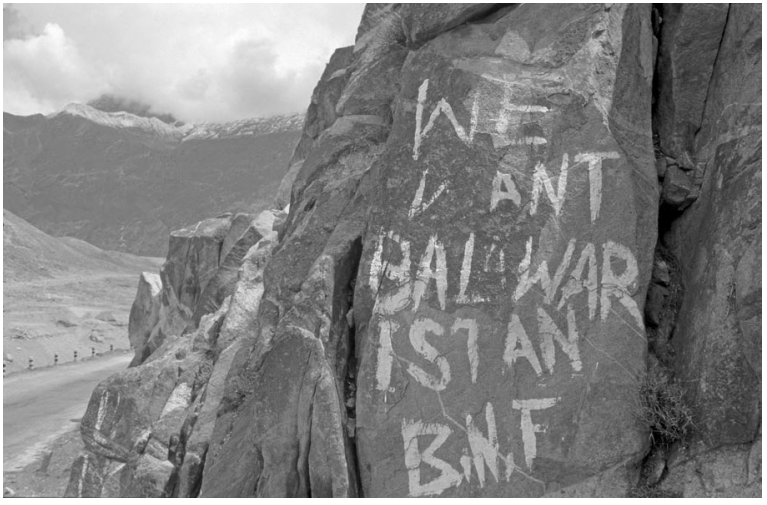

Photo 2: "Balawaristan" demand by the B.N.F.

sources (Holzwarth 1998, 300-301). Another such term is Dardistan, the favourite denomination of LEITNER who commissioned several maps in which the area is depicted. ${ }^{23)}$ Somehow Gilgit seems to be the centre of a suggested Dardistan. Again the ambiguity of the delineation provides ample space for territorial claims. Some recent protagonists of the naming game in the Northern Areas have suggested acronyms which incorporate certain alphabetic characters or syllables from existing toponyms. Constructions such as Baqahistan - incorporating "baqah" (Arabic for life) with the "-stan" suffix for area or the newly created toponym Kuhimir - a combination from the Persian words "kuh" for mountain and "mir" for ruler - were interpreted in two ways. Kuhimir could be translated as "mountain leader" as well as a semi-acronym combined from "ku" for Karakoram, "hi" for Himalaya and Hindukush, in addition the second syllable from Pamir completes the new term. ${ }^{24)}$ These experiments and suggestions try to avoid ethnic and/or religious connotations. For the purpose of a peaceful solution of the naming conflict they refer to orographic entities which were introduced from Turkic and Indic languages. Attributions such as Karakoram go back to the explorer brothers Schlagintweit in the second half of the $19^{\text {th }}$ century.

23) The maps by E. G. Ravenstein "The skeleton map of the countries between Kashmir \& Panjkorah including Chilas, Kandia \& other districts of Dardistan" in the scale 1: 500 000, published in 1875, and the "Map of the Pamirs" in the scale 1: 4 million, published 1892 in the Asiatic Quarterly Review; cf. LeitNer 1891, 1893a, b, 1894.

24) Cf. BEg 2007 who promoted such place names which he identified as un-biased due to their constructive character. Bahqahistan can be dissolved ito "Ba" for "bam-e dunya" (roof of the world), "qa" for Karakoram and "hi" for Hindukush and Himalaya. These attempts follow similar interpretation models which have been applied for the country name Pakistan.
Others would like to introduce the Northern Areas as a country of flowers (Arz-i-Gulistan). Again this is a measure not to offend any community who has got stakes in the naming-game and political representatives in the Northern Areas Legislative Council. Regional activists and lobbyists strongly suggest names such as Boloristan, mainly promoted by residents from Baltistan, Burushal promoted by speakers of Burushaski language, Dardistan would be the equivalent for Shina speakers, Sargin the term preferred by residents of Ghizer district. ${ }^{25)}$ Some inhabitants feel that Karakoram would be the appropriate term for the whole region, but then others who perceive that they might be living in the Pamir, Hindukush or Himalya repudiate them and reject this exclusionary term.

Naming conflicts occur on all levels. Since Pervez Musharraf announced the creation of a new district comprising Hunza and Nager the debate has heated up, not only regarding the seat of administration. At the same time the search for a proper name - Hunza-Nager, Brushal, Kanjut - creates enmity within the region. Naming games substitute socioeconomic competition for influence and power. They reflect the power struggles and regional tension that are prevalent in the Northern Areas. Sometimes they function as an alternative playground to disguise the contrasting viewpoints and serious rifts between different factions and lobby groups. Regionalism and sectarian disputes constitute the main confrontations in recent years.

\section{The range of ethnic conflicts in Northern Pakistan}

In the mountain regions the religious composition is different from the rest of downcountry Pakistan where about four fifths of the population identify themselves as Sunni Muslims. In Gilgit Town which is the focal point of confrontation in the North the denominational formation is tripartite. The three major denominational Muslim communities - Ismailiya, Sunna, Twelver Shia - are roughly of equal size in Gilgit Town. In rural areas regional variation is ubiquitous. While Ghizer and Hunza are dominated by Ismailis, Astore, Baltistan and Nager are predominantly Twelver Shia, whereas Chilas

25) AzIZ Ali DAD 2007. For all these terms some historical references are given going back to the work of Greek historiographers, chroniclers from different periods and colonial writers; cf. Dani 1989; Holzwarth 1998; Leitner 1893a, b, 1894. 
and Chitral are a majority Sunni region. In addition the Nurbakhshia of Ghanche in Baltistan need to be accounted for. ${ }^{26)}$ Regions are somehow associated with majority denominations.

Ethnic conflicts in the Northern Areas are primarily due to communalism-motivated sectarian clashes between the majority Shia and minority Sunni groups. In the 1980s armed clashes recurred frequently, coming to a head in 1988 when many died (Table 1). Polarization, with its concomitant identity effects, occurs primarily between the two communities. Public perception is that this is a clash between Shia and Sunni factions, very much in tune with similar confrontations in downcountry Pakistan. This obvious rift has developed since the 1980s during Zia-ul Haq's regime and his Islamization policies. ${ }^{27)}$ Lobbyism, strategies and group formation were copied in the Northern Areas and stimulated the growing confrontation. Endeavouring to contain the conflict and to mediate, the administration arranges regular meetings at which representatives of the parties concerned in the shaky peace agreement are called to account. These representatives are the Sunni Anjumane-Able Sunnat and the Anjuman-e-Imamia, which acts for the Twelver Shia population of Gilgit.

In Chitral the confrontation lines that sporadically have led to violent clashes run between the mainly Sunni south and the dominantly Ismaili north of the district. ${ }^{28)}$ As in Gilgit, Chitral's rapidly expanding district capital and the trading centres with their changing population structure are often the arenas of conflict. In rural areas, important groups are no longer formed on the basis of criteria such as language, origin and

26) Cf. Kreutzmann 2005a, b; Rieck 1995. The vast majority of the residents, above $99 \%$, profess the Muslim faith in the Northern Areas. For the Gilgit District, the latest census returned 99.74\% Muslim, for Baltistan 99.77\%, Government of Pakistan (2000, 23; 2001, 26). Only very few Ahmadi, Bahai, Buddhists, Christians and Sikhs live there and are registered.

27) Sunni sectarian organizations were founded in the 1980s (cf. GRARE 2007). On their agenda were excommunication strategies directed mainly towards Twelver Shia groups.

28) Cf. similar circumstances and motives of clashes between the two conflicting parties during the colonial period: In 1901-1902 large groups of Ismailis converted to Sunna (especially in Mulkho and Turkho) after agitation by clerics; similar events were reported in 1906 (IOL/P\&S/7/132/455: Gilgit Diary 23.2.1901; IOL/P\&S/7/143/ 468: Chitral Diary 18.2.1902; IOL/P\&S/7/189/1100: Chitral Diary 23.5.1906). In 1917, the Ismaili pir Bulbul had to leave Chitral and go into exile after he had stirred up an oppositional group from Mastuj against the Mehtar (IOL/P\&S/10/973, 75: Gilgit Diary December 1927). In the winter of 1924-1925, Ismailis started to flee from Chitral to seek asylum in Gilgit Agency, causing the colonial administration to intervene. social status, but according to membership of specific religious denominations. Hence, spatial factors are of decisive importance in questions of group formation, and changing coalitions have to be considered.

To give an example: from the perspective of the Wakhi in Northern Pakistan these questions are important because Wakhi belong to a linguistic and religious minority, as well as being involved in the conflict. In Pakistani censuses and surveys there is no breakdown of these criteria, so no data on group composition or on statistical groupings are available to the representatives of the communalistic factions or to government employees. ${ }^{29)}$ With regard to religion, the only differentiation is between Muslims and other beliefs. ${ }^{30}$ This procedure is practised throughout Pakistan and contributes to the fact that group sizes and data about members of religious groups are often manipulated for strategic reasons. Shia representatives overestimate their proportion of the population, just as the Sunnis give unrealistic figures on the groups' proportional representation. ${ }^{31)}$

The language factor poses similar difficulties: In linguistic terms, the Census of Northern Areas - the last was conducted in 1998 - included the great majority of the autochthonous population groups in the category "Other Languages", which, after all, accounted for $97.11 \%$ of the inhabitants in 1981; in 1998, they amounted to $96.9 \%$ in the Gilgit District and $98.3 \%$ in Baltistan (Government of Pakistan 1984a; 2000, 43; 2001, 26). The first census, conducted in 1951 after Pakistan's independence, had distinguished between the local language groups (Government of Azad Kashmir 1952). Since then, the category Others has not been differentiated further. The primary characteristic of this major group of local languages is that it is not written; hence, it differs from the category of national languages, for which extensive printed literatures are available. Attempts to develop appropriate scripts for local vernaculars have been made mainly by non-local linguists

29) Since the Census of India in 1931, no specific data have been published on religious groups, castes and other communities/sects neither in India nor in Pakistan.

30) The percentage of non-Muslims minorities in the Northern Areas amounts to about $0.2 \%$ of the total population (Government of Pakistan 1984a, 18; 2000, 26; 2001, 26). In Chitral (NWFP) the 4,000 Kalasha amount to $1.5 \%$. The Kalasha inhabit the Hindukush valleys of Bumburet, Birir and Rambur and are a prominent group of the kafir (unbelievers), who do not follow any of the religions of the Book. Meanwhile, almost $50 \%$ of them have converted to Islam. Studied by ethnographers at an early stage (cf. JETTMAR 1975), the Kalasha are now being marketed as an exotic ethnic group and tourist attraction.

31) Cf. the data in Usman Malik and Schimmel (1976, 205). 
and local language associations. The past few years have seen an increase in academic and private initiatives in this field (cf. Kreutzmann 1995b, 2005a, b). Because Pakistan's aim was to standardize rather than diversify its language spectrum after independence, government campaigns have not been launched to create writing systems or to introduce support measures. The schools of the mountain regions do not teach local languages; English and Urdu are the accepted media of instruction, as is usual in Pakistan.

In recent years a new dimension of dispute has occurred (cf. Table 1). Tensions between denominational groups have found a new arena. The curriculum taught in schools in Northern Areas has evoked a textbook dispute about the display of religious history and schools of thought (cf. STÖBER 2007). Representatives of the Shia community allege that the textbook boards of Pakistan over-emphasize the Sunni version of Islamic history. The academic and didactic dispute about contents in religious interpretation and Islamiat textbooks escalated in 2005 and subsequently more than 100 people lost their lives in the Northern Areas.

\section{Conclusion}

The history of territorial reorganization and creation of spatial entities has revealed that boundary-making has been taken as a strategy to mitigate prevalent encounters of contestants and/or to solve pending disputes among different stakeholders. Subdividing administrative units creates jobs in public service. Therefore the struggle for equal participation and adequate representation of the Northern Areas reflects the negotiations for sharing public resources. The disputes about districts and divisions, about the location of district headquarters and hospitals follow the same track. In a society which has limited resources for redistribution and in which certain groups enjoy outstanding privileges, the popular movements for territorial readjustments can be interpreted as a mode of searching for an equilibrium. High costs are borne by communities and the people in the Northern Areas.

Table 1: Conflict constellations in Northern Pakistan

\begin{tabular}{|c|c|c|c|}
\hline Year & Region & Groups in conflict & Effects \\
\hline 1982 & Chitral & Sunni-Ismaili & $\begin{array}{l}\text { August: Ismaili property destroyed in Chitral Bazaar, burning-down of buildings, } \\
\text { militant fights causing eight deaths }\end{array}$ \\
\hline 1983 & Gilgit & Sunni-Twelvershia & $\begin{array}{l}\text { October: militant encounters on Muslim holidays (tenth of muharram); injured } \\
\text { persons }\end{array}$ \\
\hline $1983 / 84$ & $\begin{array}{l}\text { Nager, } \\
\text { Hunza }\end{array}$ & $\begin{array}{l}\text { Twelvershia } \\
\text {-Ismaili }\end{array}$ & $\begin{array}{l}\text { October: militant encounters on Muslim holidays (tenth of mubarram); injured } \\
\text { persons }\end{array}$ \\
\hline 1985 & Gilgit & Sunni-Ismaili & $\begin{array}{l}\text { May: accusation of heresy behaviour against Ismailiya and agitation against the } \\
\text { Aga Khan Rural Support Programme by Sunni preachers from Punjab, ban against } \\
\text { such preachers and eviction from Northern Areas }\end{array}$ \\
\hline 1986 & Chilas & Sunni-Ismaili & March: fire set to Ismaili jamaat khana \\
\hline 1988 & $\begin{array}{l}\text { Gilgit } \\
\text { Town and } \\
\text { environs }\end{array}$ & Sunni-Twelvershia & $\begin{array}{l}\text { January: bomb attacks in Gilgit Bazaar } \\
\text { May: massacre (Sakwar, Jalalabad) and damage to villages and infrastructure, } \\
\text { militant fights with }>500 \text { dead persons), closure of Karakoram Highway }\end{array}$ \\
\hline 1989 & Gilgit & Twelvershia -Sunni & $\begin{array}{l}\text { October: during holiday Eid-e-Millat-un Nabi demonstrations and fighting, arrests } \\
\text { and curfew imposition }\end{array}$ \\
\hline 1989 & Chitral & Sunni-Ismaili & $\begin{array}{l}\text { October-November: campaign against the Aga Khan Rural Support Programme, } \\
\text { accusation of being a pioneer institution for the creation of an Ismaili State }\end{array}$ \\
\hline 1990 & Jaglot & Sunni-Twelvershia & $\begin{array}{l}\text { February-March: Kidnapping of a minibus with Twelvershiite and Ismaili } \\
\text { passengers, murder of all passengers in front of a Sunni clergyman; culprits and } \\
\text { suspects escape verdict and punishment: } 9 \text { persons dead, temporary arrest of } \\
\text { more than } 1500 \text { persons }\end{array}$ \\
\hline 1991 & $\begin{array}{l}\text { Gilgit, } \\
\text { Ghizer }\end{array}$ & Sunni-Twelvershia & $\begin{array}{l}\text { September: murder in cold blood of } 6 \text { Nagerkuts in Ghizer and of } 6 \text { persons in } \\
\text { addition in Gilgit } \\
\text { October: murder of } 2 \text { prominent Sunni politicians in Gilgit, ban against down } \\
\text { country preachers from Northern Areas }\end{array}$ \\
\hline
\end{tabular}


1992 Gilgit Sunni-Twelvershia May-June: militant skirmishes in Gilgit Bazaar: 15 persons dead, 38 arrests and 23 days of curfew

August-September: militant encounters in Gilgit Bazaar: 7 persons dead, 20 arrests, searches of houses, substantial confiscation of weaponry, announcement of night curfew

1992 Chitral Sunni-Ismaili August: heresy accusations by Sunni clergymen, challenge for theological debates, arrest of 25 Sunni and Ismaili preachers

1993 Gilgit, Sunni-Twelvershia

August-September: militant encounters in Gilgit Bazaar ( $>25$ dead persons), murder of 2 Sunni truck drivers from Hazara in Nager, curfew, house searches for weapons, arrest of local clergymen and ban of preachers from down country, blockage of Karakoram Highway

1996 Gilgit

Federal June: Killing of a person seeking employment in the Northern Scouts triggeredGovernment-local off a mob in Gilgit causing substantial destruction of public buildings. 1 person people dead, numerous injured followed by arrests

$1999 \quad$ Chitral Sunni-Ismaili

August: anti-Ismaili demonstrations in several settlements of Chitral in the aftermaths of the murder of a Sunni JUI leader, subsequent threats against employees of AKRSP, temporary closure of AKRSP offices in Chitral and retreat of several Ismailis from Central to Upper Chitral

$1999 \quad$ Gilgit Sunni-Shia

After the introduction of new Islamiat textbooks from the Punjab Textbook Board Aga Zhiauddin Rizvi, Shia leader in Gilgit, claims that non-equivocal and indisputable books need to be introduced. Shia and Sunni positions needed to be considered. Government authorities consent to look into the matter.

$2001 \quad$ Gilgit Sunni-Shia

Clash of Shia and Sunni students in a Gilgit highschool about the textbook issue initiates a spread of protests and strikes all over the Northern Areas where Sunni and Shia communities live

Sunni-Twelvershia January: following the national ban against sectarian organisations such as Tehriki-Jafria Pakistan (TJP), Sipah-i-Sahaba Pakistan (SSP), Lashkar-i-Taiba, Jaish-iMohammad and Tehrik Nifaz Shariat-i-Mohammadi a close-down of all their offices in the Northern Areas is announced, TJP is represented in political bodies with 12 district councillors in Gilgit and Baltistan

March: reform of national curricula and their publication

2003 Gilgit Sunni-Twelvershia

April: new Islamiat text books are commissioned on order of the Ministry of Education

June: violent protests against Islamiat curricula, sveral injured persons and arrests

2004 Gilgit and

Sunni-Twelvershia environs, Baltistan

May: Shia scholar and clergyman announces ultimatum for the implementation of new Islamiat curricula. To mitigate the dispute the bureaucracy is challenged June: 12 days of curfew in Gilgit following public unrest, 4 persons dead, educational institutions in Gilgit Town and Skardu are temporarily closed, numerous arrests of Shia demonstrators, prosecution of alleged crimes such as arson and violent attacks against public buildings and civil servants, securing of unlicensed weaponry, more than 1,000 persons demonstrate in several settlements of Baltistan

January: murder of the high-ranking Shia clergyman Aga Zhiauddin Rizvi, violent protests and retaliation: 12 persons dead, substantial property damage, imposition of curfew, until July more than 30 persons dead

March: murder of the recently deposed Superintendent of Police and four accompanying persons on their way to handover responsibilities

October: 12 persons dead and more than 100 injured civilians following violent encounters between security forces and Shia demonstrators, imposition of prolonged curfew, blockages of KKH and protest in several villages Between 1988 and 2005 it was estimated by government authorities that 373 persons were killed in the Northern Areas during sectarian clashes

2006 Gilgit Sunni-Twelvershia

The toll of the riots which started in the previous year rises to more than 100 persons dead and manifold numbers of injured. During the year the situation calms down, curfews are relaxed, but control posts and patrols remain

Source: Dawn 2.6.1988, 14. and 15.1.2002, 1.6.2003, 21.4.2004, 14.5.2004, 4., 6. and 7.6.2004, 16.6.2004, 9.-14.1.2005, 21.7.2005, 15.10.2005, 17.10.2005, 30.10.2005, 5.6.2007; Dawn Magazine 2.5.2004; The Herald October 1999, April 2005; MALIK and HunZAI 2005: 7; The Frontier Post 31.10., 4. and 6. 11.1989; 1. and 21.1.1990; 28.9., 2. and 22.10.1991, 2.-6.6.1992, 20.8.-3.9.1993; The Muslim 23. and 24. 5.1988, 21.10.1989; 19.3.1990; 27. and 29.9., 20.10.1991, 1.-6.6., 25.-28.8.1992, 20.8.-3.9., 21.9.1993; The News 27.9., 2.10.1991, 13.8.1992, 21.8.-3.9.1993; Pakistan Times 17.1.1988, 20.8.-3.9.1993, Zaigham KHAN 1996 and own interviews 


\section{References}

AbDul MaliK (2005): Village-based development in the high mountains of Pakistan: Lessons from the Aga Khan Rural Support Programme (AKRSP). In: Gyamtsho, P. (ed.): Sustainable rural development in mountainous regions with a focus on agriculture in the Tibet Autonomous Region : prodeedings of the international conference held from July 26-30, 2004, in Lhasa, TAR, P.R. China. Feldafing, 113-125.

Abdul Malik and Izhar Ali Hunzai (2005): Promise and challenge of pluralism for sustainable development in mountain areas: experience and encounters from Northern Areas and Chitral (http://www.akdn.org/mountains/11 - Pluralism and Sustainable Development (Eng).

Aitchison, C. U. (1909): A Collection of Treaties, Engagements and Sanads relating to India and Neighbouring Countries XI: The Treaties \&c, relating to the North-West Frontier Province, Baluchistan, Jammu and Kashmir, Eastern Turkistan and Afghanistan. Calcutta.

Alder, G. J. (1963): British India's Northern Frontier 186595. A Study in Imperial Policy. London.

AzIz Ali DAD (2007): Renaming the Northern Areas. In: Dawn 11.9.2007.

Aziz Siddiqui (1994): Too little, too late. In: Newsline 6 (5), 49-50.

Beg, FazAl Amin (2007): Proposed names for the Northern Areas. In: Dawn 21.9.2007.

Bнutтo, Z. A. (1972): Speeches and statements July 1, 1972 September 30, 1972. Karachi.

Dani, A. H. (1989): History of Northern Areas of Pakistan. Historical Studies (Pakistan) Series 5. Islamabad.

Dawn: 2.6.1988; 3.11. and 30.11.1999; 14.-15.1., 24.10.2002; 1.6., 9.7.2003; 21.4., 14.5., 4., 6. and 7.6., 16.6., 4.7.2004; 9.-14.1., 21.7., 1.8., 15.10., 17.10., 30.10. 2005; 20.9.2006; 20.1., 5.6., 24.-27.10.2007.

Dawn Magazine: 2.5.2004.

Delanty, G. (ed.) (2006): Europe and Asia beyond East and West. Towards a new cosmopolitism. London.

Dichter, D. (1967): The North-West Frontier of West Pakistan. A study in Regional Geography. Oxford.

Durand, A. (1888): Report on the present military position in Gilgit. Simla (IOL/P\&S/7/57).

- (1899): The making of a frontier. London (reprint: Graz 1974, Karachi 1977).

ELIAS, N. (1886): Report of a mission to Chinese Turkistan and Badakhshan in 1885-1886. Calcutta (IOL/P\&S/20/A 27).

Frontier Post, The: 31.10., 4.-6.11., 3. and 5.12.1989; 1. and 21.3.1990; 28.9., 2. and 22.10.1991; 2.-6.6., 11.11.1992; 20.8.-3.9.1993.

GidDens, A. (1985): The nation-state and violence. Contemporary Critique of Historical Materialism 2. Cambridge.

GOVERNMENT OF PAKISTAN (1984a): Pakistan Statistical Yearbook 1984. Karachi.
- (1984b): 1981 District Census Report of Northern Areas (publ. by Population Census Organization, Statistics Division). Islamabad.

- (1990): The Constitution of the Islamic Republic of Pakistan (publ. by Ministry of Law, Justice and Parliamentary Affairs, Law and Justice Division). Islamabad.

- (2000): 1998 District Census Report of Gilgit (publ. by Population Census Organization, Statistics Division). Islamabad.

- (2001): 1998 District Census Report of Baltistan (publ. by Population Census Organization, Statistics Division). Islamabad.

- Northern Areas (n.d., probably 2004): Brief on Northern Areas. Gilgit.

Grare, F. (2007): The evolution of sectarian conflicts in Pakistan and the ever-changing face of Islamic violence. In: South Asia. Journal of South Asian Studies 30 (1), 127-143.

Herald, The: October 1999, April 2005.

Holdich, T. H. (1909): Indian Borderland. London.

Holzwarth, W. (1994): Die Ismailiten in Nordpakistan. Zur Entwicklung einer religiösen Minderheit im Kontext neuer Außenbeziehungen. Ethnizität und Gesellschaft: Occasional Papers 21. Berlin.

- (1998): Change in pre-colonial times: An evaluation of sources on the Karakorum and Eastern Hindukush Regions (from 1500 to 1800). In: STELlRECHT, I. (ed.): Karakorum-Hindukush-Himalaya: Dynamics of Change. Culture Area Karakorum, Scientific Studies 4/II). Köln, 297-335.

INDIA OFFICE LIBRARY AND RECORDS: Crown Representative's Records - Indian States Residencies Gilgit, Chilas, Hunza and Nagir Files (Confidential): IOR/2/1086/303.

- Files relating to Indian states extracted from the Political and Secret Letters from India 1881-1911: IOL/ P\&S/7/132/455.

- Files relating to Indian states extracted from the Political and Secret Letters from India 1881-1911: IOL/ P\&S/7/143/468.

- Files relating to Indian states extracted from the Political and Secret Letters from India 1881-1911: IOL/ P\&S/7/189/1100.

- Departmental Papers: Political and Secret Separate (or Subject) Files 1902-1931: IOL/P\&S/10/279, 286, 588, 826, 924, 973.

Jettmar, K. (1975): Die Religionen des Hindukusch. Die Religionen der Welt 4/1. Stuttgart.

KHAN, A. W. (2005): Gilgit bleeds yet again. In: Dawn 15.1.2005.

Kreutzmann, H. (1989): Hunza. Ländliche Entwicklung im Karakorum. Abhandlungen Anthropogeographie 44. Berlin.

- (1995a): Globalization, spatial integration and their impact on sustainable development in Northern Pakistan. In: Mountain Research and Development 15 (3), 213-227. 
- (1995b): Sprachenvielfalt und regionale Differenzierung von Glaubensgemeinschaften im Hindukusch-Karakorum. Die Rolle von Minderheiten im Konfliktfeld Nordpakistans. In: Erdkunde 49 (1), 106-121.

- (2002): Streit um Kaschmir. In: Geographische Rundschau 54 (3), 56-61.

- (2005a): The Karakoram landscape and the recent history of the Northern Areas. In: BiANCA, S. (ed.): Karakoram. Hidden treasures in the Northern Areas of Pakistan. Turin, 41-76.

- (2005b): Linguistic diversity in space and time: a survey in the Eastern Hindukush and Karakoram. In: Himalayan Linguistics 4. Web-Journal. http://www.uwm.edu/ Dept/CIE/HimalayanLinguistics/Journal_2005/Kreutzmann_HLJ4.pdf

- (2008): Dividing the world: conflict and inequality in the context of growing global tension. In: Third World Quarterly 29 (4), 675-689.

Kumar, R. (2005): Making peace with partition. New Delhi.

Lamb, A. (1991): Kashmir. A disputed legacy 1846-1990. London (reprint: Karachi 1992).

- (1994): The Indian claim to Jammu \& Kashmir: conditional accession, plebiscites and the reference to the United $\mathrm{Na}$ tions. In: Contemporary South Asia 3 (1), 67-72.

LeITNER, G. W. (1891): Rough accounts of itineraries through the Hindukush and to Central Asia. In: The Imperial and Asiatic Quarterly Review, N. S. II, 243-248.

- (1893a): Dardistan. In: The Imperial and Asiatic Quarterly Review, N. S. VI, 202-207.

- (1893b): Dardistan in 1893 and the treaty with Kashmir. In: The Imperial and Asiatic Quarterly Review, N. S. VI, 422-425.

- (1894): Dardistan in 1866, 1886 and 1893. Woking (reprint: New Delhi 1978, Karachi 1985).

Lockhart, W. S. A. and Woodthorpe, R. G. (1889): The Gilgit Mission 1885-86. London.

Masoodul Mulk (1991): A microcosm of farmers strategies in Chitral. AKRSP Occasional Papers 1. Gilgit.

Mehmood Khan (1996): Prime Minister's reform package for Northern Areas. In: The Muslim 18.5.1996, 14-15.

Muslim, The: 31.5. and 20.6.1985; 23. and 24.5.1988; 21.10., 27.11.1989; 19.3.1990; 27.8., 27. and 29.9., 20.10.1991; 1.6.6., 25.-28.8., 24.9., 4.12.1992; 20.8.-3.9., 21.9., 5.10.1993.

News, The: 27.9., 2.10.1991, 13.8.1992, 21.8.-3.9.1993, 2.8. and 30.10.2007.

Pakistan Times: 17.1.1988, 20.8.-3.9.1993.

PrescotT, J. R. V. (1965): The geography of frontiers and boundaries. London.

- (1975): Map of mainland Asia by treaty. Melbourne.

- (1987): Political frontiers and boundaries. London.

Prescott, J. R. V.; Collier, H. J. and Prescott, D. F. (1977): Frontiers of Asia and Southeast Asia. Melbourne.

Raman, B. (2005): Unrest in Gilgit-Baltistan. South Asia Analysis Group Paper 1241. http://www.saag.org/papers13/ paper 1241.html (26.10.2007).
RIECK, A. (1995): Sectarianism as a political problem in Pakistan: the case of Northern Areas. In: Orient 36 (3), 429-448.

Rumford, C. (2006): Theorizing borders. In: European Journal of Social Theory 9 (2), 155-169.

Salaria, A. A. (1989): Decision on status of Northern Areas shortly. In: Dawn 12.3.1989

SAMADDAR, R. (ed.) (2002): Space, territory and the state. New readings in international politics. Hyderabad.

Sherullah Beg (1976): An introduction to Northern Areas of Pakistan. Gilgit.

SöKEFELD, M. (1997): Jang Āzādir: Perspectives on a major theme in Northern Areas' history. In: STELLRECHT, I. (ed.): The past in the present. Horizons of remembering in the Pakistan Himalaya. CAK Scientific Studies 2. Köln, 61-81.

- (1999): Bālāwaristān and other imaginations. A nationalist discourse in the Northern Areas of Pakistan. In: BEEK, M. vAN; Berteisen, K. B. and Pedersen, P. (eds.): Ladakh: culture, history, and development between Himalaya and Karakoram. Recent Research on Ladakh 8. Aarhus, 350-368.

- (2005): From colonialism to postcolonial colonialism: changing modes of domination in the Northern Areas of Pakistan. In: Journal of Asian Studies 64 (4), 939-973.

STÖBER, G. (2007): Religious identities provoked: the Gilgit 'Textbook Controversy' and its conflictual context. In: Internationale Schulbuchforschung 29, 389-411.

Tanveer Kayani and Khan, M. A. (1998): Reconstitution of provincial boundaries in Pakistan: an appraisal and suggestions. In: IsRAR-UD-DIN (ed.): Studies in Pakistan Geography. Peshawar, 263-282.

TARiQ Ali (1983): Can Pakistan survive? The death of a state. Harmondsworth.

Usman Malik, M. and Schimmel, A. (1976): Pakistan. Das Land und seine Menschen. Geschichte, Kultur, Staat und Wirtschaft. Tübingen, Basel.

WARIKOO, K. (2007): Language and politics in Jammu and Kashmir. Issues and perspectives. http://www.koshur. org/Linguistic/11.html (25.10.2007).

WORLD BANK (2002): The next ascent. An evaluation of the Aga Khan Rural Support Program, Pakistan. Washington.

Zaigham KHAN (1996): Saviours of the lost park. In: The Herald, September 1996, 142-143. 